University of Wollongong

Research Online

Faculty of Law - Papers (Archive)

Faculty of Business and Law

$1-1-2009$

\title{
Blurring the lines: maritime joint development and the cooperative management of ocean resources
}

Clive H. Schofield

University of Wollongong, clives@uow.edu.au

Follow this and additional works at: https://ro.uow.edu.au/lawpapers

Part of the Law Commons

\section{Recommended Citation}

Schofield, Clive H.: Blurring the lines: maritime joint development and the cooperative management of ocean resources 2009, Article 3 - 1-27.

https://ro.uow.edu.au/lawpapers/361

Research Online is the open access institutional repository for the University of Wollongong. For further information contact the UOW Library: research-pubs@uow.edu.au 


\title{
Blurring the lines: maritime joint development and the cooperative management of ocean resources
}

\author{
Abstract \\ The first part of the paper examines the significant extension in coastal State jurisdiction offshore and \\ outlines progress in the delimitation of maritime boundaries worldwide. Some of the problems associated \\ with lack of maritime boundary delimitation and the resultant large zones of overlapping maritime claims \\ are then highlighted. Progress in the cooperative management of ocean resources through maritime joint \\ development zones is then reviewed.

\section{Keywords} \\ Blurring, lines, maritime, joint, development, cooperative, management, ocean, resources \\ Disciplines \\ Law

\section{Publication Details} \\ Schofield, C. H. (2009). Blurring the lines: maritime joint development and the cooperative management of \\ ocean resources. Issues in Legal Scholarship, 8 (1), Article 3.
}




\title{
Issues in Legal Scholarship
}

FRONTIER ISSUES IN OCEAN LAW: MARINE RESOURCES, MARITIME BOUNDARIES, AND THE LAW OF THE SEA

\section{Blurring the Lines? Maritime Joint Development and the Cooperative Management of Ocean Resources}

\author{
Clive Schofield*
}




\title{
Blurring the Lines? Maritime Joint Development and the Cooperative Management of Ocean Resources
}

\author{
Clive Schofield
}

\begin{abstract}
The first part of the paper examines the significant extension in coastal State jurisdiction offshore and outlines progress in the delimitation of maritime boundaries worldwide. Some of the problems associated with lack of maritime boundary delimitation and the resultant large zones of overlapping maritime claims are then highlighted. Progress in the cooperative management of ocean resources through maritime joint development zones is then reviewed.
\end{abstract}




\section{Fifty Years of Expanding Maritime Claims}

When the fifty years that have elapsed since the conclusion of the Geneva Conventions in $1958^{1}$ are reviewed, perhaps the most striking development in the law of the sea and in terms of consequences for ocean governance is the tremendous increase in the maritime space coming under the jurisdiction of coastal States. Pressure towards extended coastal State maritime rights had been growing prior to the conclusion of the Geneva Conventions. In this regard, the U.S. declaration of rights over the natural resources of the continental shelf beyond the territorial sea of 1945 - often termed the "Truman Proclamation" served as an important catalyst for claims to extended jurisdiction over the continental shelf.

The 1958 Conventions sought to codify the international law rules on national claims to maritime jurisdiction and the United Nations Law of the Sea Convention (UNCLOS) ${ }^{2}$ of 1982 built on the progress made in 1958, continuing the trend towards extended coastal State maritime jurisdiction. In particular, agreement was achieved on territorial seas out to a maximum breadth of 12 nautical miles $(\mathrm{nm})^{3}$ offshore as opposed to the traditional limits of $3 \mathrm{~nm}$. This represented a notable achievement of the Third United Nations Conference on the Law of the Sea, which led to the conclusion of UNCLOS, as agreement on this issue had eluded negotiators at the both the First such Conference, which resulted in the Geneva Conventions, and the Second Conference of 1960. Crucially, the Third UN Conference on the Law of the Sea also saw the concept of the $200 \mathrm{~nm}$ exclusive economic zone (EEZ) gain general international acceptance and this was included as Part V of UNCLOS.

The introduction of the EEZ concept in particular has led to a tremendous increase in the scope of maritime space coming under national jurisdiction as

\footnotetext{
${ }^{1}$ Four Conventions emerged from the first United Nations Conference on the Law of the Sea, held in Geneva in 1958: Convention on the Territorial Sea and Contiguous Zone, opened for signature 29 April 1958, 516 UNTS 205 (entered into force 10 September 1964); Convention on the Continental Shelf, opened for signature 29 April 1958, 499 UNTS 311 (entered into force 10 June 1964); Convention on the High Seas, opened for signature 29 April 1958, 450 UNTS 11 (entered into force 30 September 1962); and Convention on Fishing and Conservation of the Living Resources of the High Sea, opened for signature 29 April 1958, 559 UNTS 285 (entered into force 20 March 1966).

${ }^{2}$ United Nations, United Nations Conventions on the Law of the Sea, U.N. Sales No.E.97.V.10 (1983). See, 1833 UNTS 3, entered into force November 16 1994, available at $<$ http://www.un.org/Depts/los/convention_agreements/convention_overview_convention.htm>.

3 Although technically the correct abbreviation for a nautical mile is "M," with the "nm" referring to nanometres. However, "nm" is widely used by many authorities (for example the UN Office of Ocean Affairs and the Law of the Sea) and appears to cause less confusion than "M," which is often taken to be an abbreviation for metres.
} 
coastal states have not been slow to take up this opportunity. ${ }^{4}$ Overall, it has been estimated that, should every coastal State make national maritime jurisdictional claims out to $200 \mathrm{~nm}$, these claims would encompass 147 million square kilometers of maritime space. This amounts to approximately 41 per cent of the area of the oceans or 29 per cent of the Earth's surface. The area of area subject to jurisdictional claims out to $200 \mathrm{~nm}$ is therefore approximately equivalent to the area of land territory on the surface of the Earth. ${ }^{5}$

Additionally, UNCLOS refined the rules relating to the continental shelf, provided for continental shelf claims that may extend beyond 200nm from the coast, where the continental margin extends that far offshore. ${ }^{6}$ At the time of this writing many coastal States with potential extended continental shelf claims had yet to make submissions to the United Nations Convention on the Limits of the Continental Shelf (CLCS). ${ }^{7}$ Nonetheless, it has been estimated that eligible coastal States may be able to advance claims to an additional five per cent of the world ocean. ${ }^{8}$

\section{The Division of the Oceans and Overlapping Claims to Maritime Jurisdiction}

These developments have transformed the extent of national claims to maritime jurisdiction and consequently have had significant implications with regard to the division of ocean spaces. In particular, the enormous extension of national

\footnotetext{
${ }^{4}$ J. R. V. Prescott and C. H. Schofield, The Maritime Political Boundaries of the World (Martinus Nijhoff Publishers 2005), at p. 9. For a global summary of claims to maritime jurisdiction see, Division for Ocean Affairs and the Law of the Sea, Office of Legal Affairs, United Nations, Table of Claims to Maritime Jurisdiction (2007) at $<$ http://www.un.org/Depts/los/LEGISLATIONANDTREATIES/PDFFILES/table_summary_of_cl aims.pdf $>$

${ }^{5}$ Figures courtesy of Dr. P.A. Symonds, Senior Adviser - Law of the Sea at Geoscience Australia (personal communication, July 2008). It should be noted, however, that not every State claims maritime jurisdiction out to $200 \mathrm{~nm}$ and that there are alternative ways of making these global calculations. For example, Pruett has calculated that should every coastal State make 200nm maritime claims, 44.5 per cent of the oceans would be subject to national jurisdiction (quoted in Prescott and Schofield, The Maritime Political Boundaries of the World, at p. 9). All these figures exclude actual and potential claims to continental shelf rights beyond $200 \mathrm{~nm}$ from the coast.

${ }^{6}$ Generally see, P.J. Cook and C.M. Carleton, eds., Continental Shelf Limits (Oxford University Press, 2000).

7 At the time of writing (July 2008) the CLCS, had received 12 Submissions from (in order of Submission): the Russian Federation (2001), Brazil (2004), Australia (2004), Ireland (2005), New Zealand (2006), France, Ireland, Spain and the United Kingdom (joint submission) (2006), Norway (2006), France (2007), Mexico (2007), Barbados (2008), the United Kingdom (2008), and Indonesia (2008). See the CLCS website for further details at $<$ http://www.un.org/Depts/los/clcs_new/clcs_home.htm>.

${ }^{8}$ Ibid. at p. 3.
} 
maritime claims seawards has resulted in a proliferation in 'new' potential maritime boundaries. As a consequence of these developments, coastal States $400 \mathrm{~nm}$ or more distant from one another suddenly found themselves to be maritime neighbours with potentially overlapping maritime claims to jurisdiction. Indeed, in the case of extended continental shelf claims, coastal States whose nearest land territories are located in excess of $700 \mathrm{~nm}$ distant from one another have a potential maritime boundary between them. ${ }^{9}$

Significant progress has undoubtedly been made in the delimitation of maritime boundaries. Many contentious maritime boundary disputes are resolved, and a wealth of experience has been built up in relation to the delimitation of maritime boundaries and ocean boundary dispute resolution. ${ }^{10}$ The task is, however, a daunting one and is currently far from completion with fewer than half of the potential maritime boundaries around the world having been even partially delimited. ${ }^{11}$ Given the relatively recent nature of the maritime claims in question, many of which have only been advanced since the 1970s onwards, however, it is perhaps unsurprising that the maritime political map of the world is far short of completion.

Perhaps inevitably, just as many 'new' maritime boundaries have been created, there has likewise been a proliferation in and overlapping claims to maritime jurisdiction and maritime boundary disputes. While a distinction can be drawn between merely undelimited maritime boundaries and active maritime

9 In accordance with UNCLOS, Article 76(5), coastal State claims "either shall not exceed 350 nautical miles from the baselines from which the breadth of the territorial sea is measured or shall not exceed 100 nautical miles from the 2,500 metre isobath." The coastal State may therefore chose the most seaward of these constraint lines. Thus, assuming the existence of continental margin capable of being claimed by the coastal States under UNCLOS Article 76(4), where the $2,500 \mathrm{~m}$ isobath is further seaward than the $350 \mathrm{~nm}$ limit, coastal States in excess of $700 \mathrm{~nm}$ from one another may need to delimit a maritime boundary between their extended shelf jurisdictions.

10 See, in particular, the compendium of maritime boundary agreements contained in the International Maritime Boundaries series of volumes: J.I. Charney and L.M. Alexander, eds., International Maritime Boundaries, Vols. I and II (Martinus Nijhoff Publishers 1993); J.I. Charney and L.M. Alexander, eds., International Maritime Boundaries, Vol. III (Martinus Nijhoff 1998); J.I. Charney and R.W. Smith, eds., International Maritime Boundaries, Vol. IV (Martinus Nijhoff 2002); and, D.A. Colson and R.W. Smith, International Maritime Boundaries, Vol. V (Martinus Nijhoff 2005).

${ }^{11}$ Even reaching a clear understanding of the number of potential maritime boundaries worldwide is problematic as certain assumptions need to be made such as whether to count maritime boundaries composed of multiple distinct segments as one boundary or several. It is, furthermore, difficult to predict the number of potential maritime boundaries that may need to be delimited beyond $200 \mathrm{~nm}$ from the coast, given that many coastal States have yet to make extended claims to continental shelf claims. (M.A. Pratt, International Boundaries Research Unit, personal communication, June 2008. See also, Prescott and Schofield, The Maritime Political Boundaries of the World, at pp. 217-218.) 
boundary disputes, the existence of broad areas of competing claims to the same maritime space is problematic.

Where overlapping maritime claims exist, the resultant uncertainty over jurisdiction may well complicate ocean resource management. With regard to living resources, sustainable management of such resources can be severely hampered through, at the least, uncoordinated policies and, at the more severe end of the spectrum, potentially destructive and unsustainable competition for access to the resources in question. Such activities can lead to confrontation between, for example, rival fishing fleets, and such friction can lead to the involvement of the armed forces of the coastal States concerned with the attendant potential for incidents, clashes and ultimately escalation towards conflict. In short, such rival maritime claims can act as a major irritant in bilateral relations.

It is also the case that the presence of overlapping claims generally tends to prevent access to any seabed hydrocarbon resources that may be present in the disputed area. International oil and gas companies tend to be adverse to conducting exploration operations, let alone exploiting seabed resources, without fiscal and legal certainty and continuity. Furthermore, uncertainty over jurisdiction necessarily leads to uncertainty over surveillance and enforcement rights, potentially undermining maritime security.

\section{Alternatives to Delimitation: The Rise of Maritime Joint Development}

The past five decades have also witnessed significant steps forward in maritime cooperation in relation to areas of overlapping claims to maritime jurisdiction. In particular, maritime joint development zones have emerged as an important means to overcome deadlock in relation to maritime jurisdictional claims. Where overlapping claims exist and the parties have reached a deadlock in maritime boundary delimitation negotiations, the alternative of a shared rather than unilateral management regime may prove attractive. Although a number of these cooperative mechanisms predate UNCLOS, for example the Bahrain-Saudi Arabia joint arrangement was concluded in the same year as the signature of the Geneva Conventions (see below), such joint maritime zones have, however, become increasingly prevalent since the advent of UNCLOS. Indeed, UNCLOS Articles 74(3) and 83(3) provide a clear legal basis for maritime joint development zones. These articles state, in identical terms that:

Pending agreement as provided for in paragraph 1, the States concerned, in a spirit of understanding and cooperation, shall make every effort to enter into provisional arrangements of a practical nature and, during this transitional period, not to jeopardize or 
hamper the reaching of the final agreement. Such arrangements shall be without prejudice to the final delimitation. ${ }^{12}$

State practice in maritime joint development, reviewed below, can be broadly divided into joint zones which have been agreed in addition to a maritime boundary line, and those that have been defined in the absence of a boundary line, which have proved a more popular alternative. Six examples of joint zones concluded in conjunction with the delimitation of a maritime boundary line, and sixteen where no boundary line has yet been drawn, are reviewed below. ${ }^{13}$

\section{Joint Development Agreements in Addition to a Boundary Line}

A number of joint zones have been defined in conjunction with the delimitation of a maritime boundary between the parties concerned. In these circumstances, the joint zone may act as a catalyst for reaching agreement on the delimitation line, for example providing both parties with some rights in the maritime area of interest and therefore countering the potential drawback of defining a boundary line and subsequently discovering that the bulk, or all, of the resources in the area subject to overlapping maritime claims falls on the "other" side of the line.

\section{Bahrain-Saudi Arabia}

Signed in January 1958, this agreement represents the first maritime joint development agreement worldwide. ${ }^{14}$ It stands apart from subsequent practice because the entirety of the "joint" zone designated under the agreement lies on one side, in this case the Saudi Arabian side, of the $98.5 \mathrm{~nm}$ boundary line also defined by the treaty. The hexagonal zone designated under the agreement essentially encompasses the Fasht Abu-Sa'fah oilfield which had previously been contested between the parties. The agreement provides that the exploitation of the oil resources in this area will be carried out in the way chosen by the King of

\footnotetext{
${ }^{12}$ UNCLOS, Articles 74(3) and 83(3).

${ }^{13}$ Brief outlines of the key attributes of each of the maritime joint developments are provided here. Greater emphasis has, however, been devoted to those joint zones in the Asia-Pacific region, reflecting the focus of the present symposium. It is worth noting that the joint development arrangements reviewed do not comprise an exhaustive list of all such mechanisms. For example, a number of joint arrangements that are now defunct, such as that which existed offshore the, now divided, Kuwait-Saudi Arabia Neutral Zone, are not considered here.

${ }^{14}$ Bahrain- Saudi Arabia Boundary Agreement Dated 22 February 1959 (signed 22 February 1958 , entered into force 26 February 1958). Treaty text available at $<$ www.un.org/Depts/los/LEGISLATIONANDTREATIES/PDFFILES/TREATIES/BHRSAU1958BA.PDF>. See also, Charney and Alexander, International Maritime Boundaries 1993, Vol. II, at pp. 1489-1497.
} 
Saudi Arabia "on the condition that he grants to the Kingdom of Bahrain one half of the net revenue accruing to the Government of Saudi Arabia and arising from this exploitation."15 It can be argued that the definition of the zone from which both parties gained equal access to the proceeds from seabed resource exploitation was crucial to their successfully reaching agreement on the course of the maritime boundary.

\section{Argentina-Uruguay}

The Rio de la Plata Treaty concluded between Argentina and Uruguay in 1973 provides not only for the delimitation of the parties' boundary within the river and its estuary and their maritime boundary extending into the South Atlantic, but for the establishment of a "common fishing zone" and a joint Administrative Commission. ${ }^{16}$ The common fishing zone encompasses the area seaward of the parties' $12 \mathrm{~nm}$ territorial sea limits defined "by two arcs of circles with radii of 200 nautical miles whose centre points are, respectively, Punta del Este (Uruguay) and Punta del Cabo San Antonio (Argentina)."17

The joint Administrative Commission is tasked with promoting joint scientific research relating to, particularly, "the evaluation, conservation, preservation and rational use of living resources and the prevention and elimination of pollution," prescribing fishery standards and aiding navigation, for example through coordinating pilotage regulations, search and rescue plans and aids to navigation. ${ }^{18}$ Within the river, as defined by the headlands mentioned above, the treaty prohibits the dumping of hydrocarbons resulting from the washing of tanks and the pumping of bilge and ballast. ${ }^{19}$ Seabed resource development falls outside the purview of the joint Commission but there it is understood that each party has the right to exploit any resources discovered up to the established boundary line ${ }^{20}$ and that where deposits extend across the boundary line they "shall be exploited in such a way that the distribution of the

\footnotetext{
${ }^{15}$ Ibid. Second Clause.

${ }^{16}$ Agreement between the Government of Argentina and the Government of Uruguay Relating to the Delimitation of the River Plate and the Maritime Boundary Between Argentina and Uruguay, (signed 19 November 1973, entered into force 12 February 1974). Treaty text available at: $<$ www.un.org/Depts/los/LEGISLATIONANDTREATIES/PDFFILES/TREATIES/URYARG1973MB.PDF>. See also, Charney and Alexander, International Maritime Boundaries 1993, Vol. II, at pp. 757-766.

${ }^{17}$ Ibid. Article 73.

${ }^{18}$ Ibid. Article 66.

${ }^{19} \mathrm{Ibid}$. Article 78.

${ }^{20}$ Ibid. Article 42.
} 
amounts of the resource extracted from them is proportional to the amounts of that resource lying on each side of the line."21

\section{Australia-Papua New Guinea}

Australia and Papua New Guinea (PNG) concluded a treaty dealing with sovereignty and maritime boundaries in the maritime areas between them, notably the Torres Strait, in $1978 .^{22}$ The agreement is a complex one that took six years to negotiate and a further six years to ratify as a result of the novel implementing legislation required..$^{23}$ The area to be delimited, and the Torres Strait in particular, is geographically complex and host to a profusion of islands. The agreement provided for recognition of each side's sovereignty over particular islands and confirmed that most of the islands in the Torres Strait are under Australian sovereignty. $^{24}$ Key elements in the agreement, which facilitated the comprehensive resolution of outstanding issues between the parties, included the establishment of a protected zone encompassing the Torres Strait, the enclaving of certain Australian islands, ${ }^{25}$ and the separation of the seabed and water column boundaries within that zone.

The objective of the protected zone was to safeguard traditional fishing activities and the free movement of traditional inhabitants, to regulate commercial fisheries, and to protect the marine environment. The agreement included a moratorium on oil and gas exploration within the protected zone. A particularly innovative aspect of the agreement was the delimitation of separate continental shelf and fisheries boundaries within the joint zone. It was agreed to separate

${ }^{21}$ Ibid. Article 43.

22 Treaty between Australia and the Independent State of Papua New Guinea concerning sovereignty and maritime boundaries in the area between the two countries, including the area known as Torres Strait, and related matters, 18 December 1978 (entry into force, 15 February 1985). Treaty text available at [1985] ATS 4 and

$<$ www.un.org/Depts/los/LEGISLATIONANDTREATIES/PDFFILES/TREATIES/AUS-

PNG1978TS.PDF>. See also, Charney and Alexander, International Maritime Boundaries 1993, at pp. 929-975.

${ }^{23}$ Charney and Alexander, International Maritime Boundaries 1993, at p. 929.

${ }^{24}$ Treaty between Australia and Papua New Guinea, Article 2. Australia did, however, recognise Papua New Guinea's sovereignty over three uninhabited islands (Kawa, Mata Kawa and Kussa Islands) that it had previously regarded as Australian (Article 2(3)).

${ }^{25}$ The agreement provides that the territorial seas of specific, listed, islands "shall not extend beyond three miles" from the relevant baselines and that, furthermore, the territorial seas in question "shall not be enlarged or reduced, even if there were to be any change in the configuration of the coastline or a different result from any further survey." This had the consequence of creating $3 \mathrm{~nm}$ breadth territorial sea enclaves around several Australian islands located in the northern part of the Torres Strait (Treaty between Australia and Papua New Guinea, Article 3). 
jurisdiction for the seabed and water column in order to take into consideration the existence of numerous Australian islands in the northern parts of the Torres Strait extremely near to the Papua New Guinean coast (the closest being only approximately $500 \mathrm{~m}$ offshore). Had a delimitation line been defined on the basis of equidistance, the presence of these islands would have resulted in the vast majority of the Torres Strait being located on the Australian side of the line. Such an outcome was viewed as an inequitable one and instead a continental shelf boundary was defined centrally in the Strait, midway between the mainland coasts of both States, while a fisheries boundary, passing close to the PNG coast, was defined around the Australian islands in the northern part of the Torres Strait. Thus, in this area PNG seabed underlies Australian water column. The Torres Strait Treaty provided for the establishment of a joint advisory council was set up to promote cooperation, ${ }^{26}$ and also provides a for detailed regulatory regime which is designed to protect traditional rights while promoting cooperative development of commercial fisheries. ${ }^{27}$

\section{Iceland-Norway (Jan Mayen Island)}

In 1980 Iceland and Norway reached agreement on a maritime boundary relating to the EEZ, to be based on $200 \mathrm{~nm}$ arcs measured from basepoints on Iceland. ${ }^{28}$ The agreement referred the question of continental shelf delimitation to a Conciliation Commission. This body subsequently made recommendations that whilst the continental shelf boundary should coincide with the EEZ boundary, a joint zone should also be established and a further treaty between the parties was concluded in 1981 which gives effect to the recommendations of the Conciliation Commission. ${ }^{29}$ The $45,470 \mathrm{~km}^{2}$ joint zone established under the 1981 agreement unevenly straddles the maritime boundary line with 61 per cent on the Norwegian

\footnotetext{
${ }^{26}$ See, for example, Kaye, S.B. Australia's Maritime Boundaries, $2^{\text {nd }}$ edition, Wollongong Papers on Maritime Policy, 12 (Centre for Maritime Policy 2001), at pp. 104-105; and Renton, D. (1995) "The Torres Strait Treaty after 15 Years: Some Observations from a Papua New Guinean Perspective," pp.171-180 in Crawford, J.R. and Rothwell, D.R., eds., The Law of the Sea in the Asian Pacific Region (Martinus Nijhoff 1995).

${ }^{27}$ Article 23 of the treaty, revenues are split 75:25 according to whose jurisdictional sector of the zone the fish are caught in.

${ }^{28}$ Agreement between Norway and Iceland on Fishery and Continental Shelf Questions, 28 May 1980 (entered into force 13 June 1980). Treaty text available at $<$ www.un.org/Depts/los/LEGISLATIONANDTREATIES/PDFFILES/TREATIES/islnor1980fcs.pdf $>$.

${ }^{29}$ Agreement on the Continental Shelf between Iceland and Jan Mayen, 22 October 1981 (entered into force 2 June 1982). Treaty text available at $<$ www.un.org/Depts/los/LEGISLATIONANDTREATIES/PDFFILES/TREATIES/ISLNOR1981CS.PDF>. See also, Charney and Alexander, International Maritime Boundaries 1993, at pp. $1755-1765$.
} 
side and 39 per cent on the Icelandic side. Each state is entitled to 25 per cent of revenues deriving from the exploitation of oil and gas on the other side of boundary. ${ }^{30}$ Moreover, hydrocarbon fields straddling the joint zone and Icelandic waters are considered wholly Icelandic. ${ }^{31}$ The delimitation of the maritime boundary along 200nm arcs drawn from Iceland was designed to recognise Iceland's "strong economic dependence on fisheries" as well as its greater size and population relative to Jan Mayen. The confirmation of the continental shelf boundary being coincident with the water column boundary and uneven distribution of the joint zone across the delimitation line, which also favoured Iceland, also took the disparity between Iceland and Jan Mayen into account. Additionally, Iceland's lack of mineral resources was a factor in the recommendations of the Conciliation Commission. ${ }^{32}$

\section{Denmark-United Kingdom}

In May 1999 Denmark and the United Kingdom concluded a maritime boundary agreement for the area between the Faroe Islands and Scotland. ${ }^{33}$ A maritime boundary extending for approximately $500 \mathrm{~nm}$ was delimited. ${ }^{34}$ Although the continental shelf and fisheries zone boundaries are coincident for much of the agreed line, in the central part of the boundary, a continental shelf boundary was defined together with a "Special Area" of joint fisheries jurisdiction. The Special Area covers an area of $2,337 \mathrm{~nm}^{2}$ or approximately $8,000 \mathrm{~km}^{2} .{ }^{35}$ The Special Zone straddles the continental shelf boundary but does so in unequal manner, the majority of it being located on the UK side of the seabed boundary line. This reflected the overwhelming dependence of the Faroe Islands economy on fisheries. ${ }^{36}$ Within the Special Zone each party has the right to continue to conduct fishery operations, including the issuing of licences and agreement was reached to "refrain from inspection and control of fishing vessels" operating in the joint zone under a licence issued by the other party and to refrain from any action

\footnotetext{
${ }^{30}$ Agreement on the Continental Shelf between Iceland and Jan Mayen, Articles 5 and 6.

${ }^{31}$ Ibid. Article 8.

${ }_{32}^{32}$ Charney and Alexander, International Maritime Boundaries 1993, at p. 1757.

${ }^{33}$ Agreement between the Government of the Kingdom of Denmark together with the Home Government of the Faroe Islands on the one hand and the Government of the United Kingdom of Great Britain and Northern Ireland on the other hand relating to the Maritime Delimitation in the area between the Faroe Islands and the United Kingdom, 18 May 1999 (entered into force 21 July 1999). Treaty text available at $<$ www.un.org/Depts/los/LEGISLATIONANDTREATIES/PDFFILES/TREATIES/DNKGBR1999MD.PDF>. See also Charney and Smith, International Maritime Boundaries 2002, at pp. 2955-2977.

${ }^{34}$ Charney and Smith, International Maritime Boundaries 2002, at p. 2956.

${ }^{35}$ Ibid.

${ }^{36}$ Ibid. 2959-2960.
} 
that would "disregard or infringe" the fisheries jurisdiction of the other party or conduct of fisheries under licence by the other party. ${ }^{37}$ Both the Denmark and UK also undertook to take "all possible steps to prevent and eliminate pollution" resulting from their offshore activities and committed to a series of measures to ensure that fishing activities can continue unhindered by, for example, exploration activities related to seabed hydrocarbon resources. ${ }^{38}$ The two States also agreed to cooperate on measures to protect the marine environment. ${ }^{39}$

\section{China-Vietnam}

China and Vietnam concluded a maritime boundary agreement in the Gulf of Tonkin (Beibu Gulf to China and Bac Bo Gulf to Vietnam) in December $2000 .^{40}$ Allied to the boundary treaty an Agreement on Fishery Cooperation in the Gulf of Tonkin was concluded. As fisheries are a particularly important, and in the past contentious, issue in the Gulf of Tonkin, the joint fisheries agreement and joint arrangements to manage fisheries activities can be considered to be vital to reaching agreement on the delimitation of the maritime boundary line, a contention supported by the fact that the fisheries agreement was both signed and ratified on the same dates as the maritime boundary treaty. ${ }^{41}$ Through the fisheries cooperation agreement a joint Common Fishery Zone was defined which straddles the maritime delimitation line, $30.5 \mathrm{~nm}$ on either side of the boundary, from the $20^{\circ} \mathrm{N}$ parallel of latitude to the closing line of the Gulf. ${ }^{42}$ The Common Fishery Zone therefore encompasses approximately 30,000 $\mathrm{km}^{2}$ (around $8,747 \mathrm{~nm}^{2}$ ). ${ }^{43}$ In institutional terms, the agreement also provided for a powerful Joint Fisheries Committee with a view to determining critical issues such as fishing quotas and the number of vessels from each side to be licensed to fish in the joint zone as well as to promote long-term cooperation and management. Importantly, enforcement within this joint zone is conducted on the basis of coastal State authority, that is, on the basis of which side of the defined boundary line the

\footnotetext{
${ }^{37}$ Denmark-UK Agreement, Article 5.

${ }^{38}$ Ibid. Article 6.

${ }^{39}$ Ibid. Article 7.

${ }^{40}$ Agreement between the People's Republic of China and the Socialist Republic of Viet Nam on the Delimitation of the Territorial Sea, the Exclusive Economic Zone and Continental Shelf in Beibu Bay/Gulf of Tonkin (25 December 2000) and Agreement between the People's Republic of China and the Socialist Republic of Viet Nam on Fisheries Cooperation for the Gulf of Tonkin. For treaty text, see <www.un.org/Depts/los/legislationandtreaties.htm $>$. See also Colson and Smith, International Maritime Boundaries, at pp. 3745-3758.

${ }^{41}$ Colson and Smith, International Maritime Boundaries, at p. 3748.

42 Ibid.

${ }^{43}$ Keyuan, Z., "The Sino-Vietnamese Agreement on Maritime Boundary Delimitation in the Gulf of Tonkin," Ocean Development and International Law, 36 (2005), 13-24, at p. 16.
} 
activity takes place, rather than on the basis of flag state control. Additionally, a transitional arrangement zone north of $20^{\circ} \mathrm{N}$ was established where the parties aim to gradually reduce the number of fishing vessels operating. A buffer zone either side of the parties' territorial sea boundary, in the immediate vicinity of the terminus of the land boundary on the coast in the north of the Gulf, was defined in order to minimise disputes involving for small fishing vessels that may have trespassed across the boundary line. ${ }^{44}$

\section{Joint Development Agreements in Lieu of a Boundary Agreement}

\section{Cambodia-Vietnam}

Cambodia and Vietnam reached agreement in 1982 on the establishment of a joint area of "historic waters" in the Gulf of Thailand. ${ }^{45}$ The oblong-shaped joint zone extends seawards from the mainland coastlines of the two countries out to the vicinity of the Poulo Wei group of islands, which were specified as Cambodian, and the Tho Chu (Poulo Panjang) islands which according to the agreement were determined to be Vietnamese, as was the large island of Phu Quoc. No maritime boundary was defined through the joint area, though it was stated that negotiations on this issue would take place "at a suitable time." 46 The primary purpose of the agreement appears to have been the resolution of the parties' dispute over these islands, sovereignty over which had previously been contested, as well as the integration of their straight baseline systems which meet at "Point O," whose precise location is unspecified, on the south-western limit of the historic waters area. ${ }^{47}$ The agreement does, however, include some maritime joint development provisions. Cambodia and Vietnam agreed to undertake the exploitation of natural resources within the joint historic waters area on the basis of "common agreement," to allow fishermen to continue their activities in the joint zone "according to the habits that have existed so far," and to carry out joint surveillance and patrols in the joint area. ${ }^{48}$ Cambodia and Vietnam's claim to the establishment of such a unique joint historic waters area, and to joining their

\footnotetext{
${ }^{44}$ Ibid. 3749. See also, Thao, N.H., "Maritime Delimitation and Fishery Cooperation in the Tonkin Gulf," Ocean Development and International Law, 36 (2005), at pp. 25-44.

${ }^{45}$ Agreement on Historic Waters of Vietnam and Kampuchea, 7 July 1982 (entered into force 7 July 1982). See, Charney and Alexander, International Maritime Boundaries 1998, at pp. 23642365.

${ }^{46}$ Agreement on Historic Waters of Vietnam and Kampuchea, Article 2.

${ }^{47} \mathrm{Ibid}$. Article 3.

${ }^{48}$ Ibid.
} 
respective straight baseline systems at an apparently "floating" point out to sea, drew international protests, notably from Thailand ${ }^{49}$ and the United States. ${ }^{50}$

\section{Japan-Korea}

Although Japan and the Republic of Korea were able to delimit a maritime boundary between their respective territories in the southern part of the Sea of Japan (East Sea to Korea) and through the Korea Strait, ${ }^{51}$ their contending positions on the applicable principles and methods of delimitation in respect of the southern part of their potential continental shelf boundary extending into the East China Sea were significantly different and proved to be irreconcilable. ${ }^{52}$ In particular, whilst Japan based its position on the equidistance or median line approaches, Korea asserted that, on the basis of natural prolongation arguments, its continental shelf extended beyond the median line.

The Japan-Korea agreement of 1974 dealt with the broad area of overlapping claims to maritime jurisdiction by establishing a maritime joint development zone designed to facilitate the exploration for and exploitation of seabed oil and gas

49 Thailand protested against the agreement in a Note to the UN Secretary General dated 9 December 1985, stating that: "Regarding the claims to the so-called 'historic waters', which purport to appropriate and subject certain sea areas in the Gulf of Thailand and in the Gulf of Tonkin (Gulf of Bac Bo) to the regime of internal waters, the Government of Thailand is of the view that such claims cannot be justified on the basis of the applicable principles and rules of international law," UN Law of the Sea Bulletin 7 (April 1986), at p. 111.

${ }^{50}$ In a Note to the UN Secretary General dated 17 June 1987, the United States government protested against the Cambodian-Vietnamese agreement, stating that the claim was made known internationally "less than five years ago" and the short period of time that it had been in existence was "insufficient" to demonstrate the required effective exercise of authority for such a historic claim. Furthermore, with regard to the issue of acquiescence, the U.S. Note continued, "the United States has not acquiesced in this claim, nor can the community of States be said to have done so. Given the nature of the claim first promulgated in 1982, such a brief period of time would not permit sufficient acquiescence to mature," UN Law of the Sea Bulletin 10 (November 1987), at p. 23. See also J.A. Roach and R.W. Smith, United States Responses to Excessive Maritime Claims, 2nd edition (Martinus Nijhoff Publishers 1996), at pp. 39-40; and Schofield, C.H. and TanMullins, M. "Claims, Conflicts and Cooperation in the Gulf of Thailand," Ocean Yearbook, 22 (Martinus Nijhoff 2008), at pp. 91-92.

51 Agreement between Japan and the Republic of Korea Concerning the Establishment of Boundary in the Northern Part of the Continental Shelf Adjacent to the Two Countries, 30 January 1974 (entered into force 22 June 1978). Treaty text available at:

$<\quad$ http://www.un.org/Depts/los/LEGISLATIONANDTREATIES/PDFFILES/TREATIES/japkor1974north.tif $>$. See also Charney and Alexander, International Maritime Boundaries 1993, at pp. 1057-1089.

${ }^{52}$ The parties' dispute over sovereignty concerning the islands of Dok-do (to Korea) or Takeshima (to Japan) also frustrated progress towards the delimitation of a maritime boundary further north. 
resources and covering an area of 29,092 $\mathrm{nm}^{2}{ }^{53}$ While the issue of boundary delimitation within the joint zone was shelved, ${ }^{54}$ the agreement on joint development was achieved in conjunction with the partial boundary agreement directly to the north mentioned above, which stretches for $263 \mathrm{~nm}$. The agreement, which entered into force in 1978 and was set to last for 50 years, ${ }^{55}$ originally called for the definition of nine sub-zones within the overall joint zone, although the number of sub-zones was reduced to six following surveys indicating that the likelihood of seabed hydrocarbons being present was limited. Within each sub-zone, concessionaires, authorised by the each of the parties, have an undivided interest and one operator is chosen from among the two concessionaires to conduct activities in a particular sub-zone. ${ }^{56}$ This "operator formula" approach also has implications for the application of the parties' respective laws and regulations within the joint zone, with Japanese law applying to a Japanese operator within a particular sub-zone and Korean law applying to a Korean operator a sub-zone that may be adjacent. ${ }^{57}$

The costs incurred by the parties in the exploration and exploitation phases are to be shared equally between the concessionaires of the two countries, as are the proceeds from the natural resources extracted in a sub-zone. The agreement establishing the joint development zone also includes an undertaking that the seabed resource exploration and exploitation activities are to be conducted in such a way that other legitimate activities within the joint zone, notably navigation and fishing, are not to be unduly affected. ${ }^{58}$ The parties also established a Joint Commission ${ }^{59}$ in order to facilitate liaison between the governments concerned, though they stopped short of setting up a more powerful joint authority. To date, exploration activities have failed to result in the discovery of commercially viable oil and gas reserves.

\footnotetext{
${ }^{53}$ Agreement between Japan and the Republic of Korea Concerning Joint Development of the Southern Part of the Continental Shelf Adjacent to the Two Countries, 30 January 1974 (entered into force 22 June 1978). Treaty text available at

$<$ http://www.un.org/Depts/los/LEGISLATIONANDTREATIES/PDFFILES/TREATIES/jakor1974south.tif $>$.

${ }^{54}$ Article 28 of the Japan-Korea treaty states that: "Nothing in the Agreement shall be regarded as determining the question of sovereign rights over all or any portion of the Joint Development Zone or as prejudicing the positions of the respective Parties with respect to the delimitation of the continental shelf."

${ }^{55}$ The agreement may be extended if no maritime boundary is delimited, although it can be terminated by either side with three years' notice (Japan-Korea treaty, Article 31(2)).

${ }^{56}$ Thus a joint venture or consortium is not allowed for the exploration or exploitation of any of the sub-zones. For details on licensing in the Japan-South Korea Agreement, see Miyoshi (1993).

${ }^{57}$ Article 19 of the Japan-Korea treaty provides that: "the laws and regulations of one Party shall apply with respect to matters relating to exploration and exploitation of natural resources in the subzones with respect to which the Party has authorized concessionaires designated and acting as operators."

${ }^{58}$ Japan-Korea treaty, Article 27.

${ }^{59}$ Ibid. Article 24.
} 
Had oil and gas been discovered, a potentially major additional complication and disincentive to development is the fact that China claims parts of the Japan-Korea joint zone and has refused to recognise its creation. ${ }^{60}$ China, just as is the case for Korea, also bases its continental shelf claims in the East China Sea on natural prolongation arguments and, it is understood, consequently claims a significant portion of the Japan-Korea joint development area.

\section{Saudi Arabia-Sudan}

The joint zone defined between the Saudi Arabia and Sudan in $1974^{61}$ stands apart from other maritime joint development zones as its area of application is not defined by a series of geographic coordinates joined by lines. Instead, the joint zone applies to that part of the central part of the Red Sea between the two countries' respective coasts which is greater than 1,000 metres in depth. The northern and southern limits of the joint zone have not, however, been defined. Although the agreement covers all natural resources, its primary objective was to allow for the joint exploration for and exploitation of the seabed mineral resources, notably metalliferous sediments rich in heavy metal such as copper, manganese, zinc, iron and silver, known to exist in the Red Sea deeps, especially off Sudan. ${ }^{62}$ Although a Saudi-Sudanese Red Sea Commission was established in 1975 , it is understood that little exploration activity has in fact taken place and no commercial discoveries or developments have eventuated. ${ }^{63}$

\section{Australia-Indonesia}

Australia's seabed boundaries with Indonesia in the Timor Sea of 1972 were negotiated prior to Indonesia's 1975 occupation and subsequent annexation of East Timor, creating a discontinuity in the line which became commonly referred to as the "Timor Gap." Following Indonesia's invasion of East Timor and Canberra's subsequent acceptance of Indonesian sovereignty over East Timor, boundary negotiations for the Timor Gap were initiated in order to join up the separate sections of their existing maritime boundary agreements to the east and west. However, international law had, in the intervening time, evolved, apparently weakening Australia's "natural prolongation" arguments concerning separate continental shelves. Additionally, the Indonesians strongly felt that they had been

\footnotetext{
${ }^{60}$ Charney and Alexander, International Maritime Boundaries 1993, at p. 1058.

${ }^{61}$ Agreement Relating to the Joint Exploration of the Natural Resources of the Seabed and Subsoil of the Red Sea in the Common Zone, 16 May 1974.

${ }^{62}$ Prescott and Schofield, The Maritime Political Boundaries of the World, at p. 488.

63 Dzurek, D.J., Parting the Red Sea: Boundaries, Offshore Resources and Transit, Maritime Briefing, 3, 2 (International Boundaries Research Unit, 2001), at p. 16.
} 
short-changed in the earlier boundary agreements. ${ }^{64}$ As a result no boundary agreement could be reached regarding the Timor Gap, which was, instead, closed with a joint development zone - the Timor Gap Zone of Cooperation. ${ }^{65}$

The treaty itself was signed in December 1989 with additional detailed regulations being added in 1991, and was widely regarded as the most sophisticated and comprehensive maritime joint development zone in the world. ${ }^{66}$ Covering an area of $60,500 \mathrm{~km}^{2}$ the Timor Gap arrangement effectively plugs the Timor Gap and was divided into three sub-zones - a large central, "sovereignty neutral," Zone A where revenues were to be shared on a 50:50 basis, and two smaller "national" zones, Zone B to the south where sharing was on the ratio 90:10 in favour of Australia and a narrow Zone C, where the ratio was 90:10 in favour of Indonesia. The initial duration of the agreement was to be 40 years, to be followed by successive terms of 20 years. The Timor Gap Treaty is, however, no longer in force, having been replaced by agreements concluded between Australia and East Timor (see below).

\section{Malaysia-Thailand}

Although Malaysia and Thailand were able to agree on the alignment of their territorial sea boundary without undue difficulty, ${ }^{67}$ they were only able to delimit their continental shelf boundary out to a point approximately $29 \mathrm{~nm}$ offshore. ${ }^{68}$ Seaward of that point, a dispute over the validity of a small Thai island as a basepoint led to a roughly wedge-shaped overlap in continental shelf claims. A Memorandum of Understanding (MoU) was concluded between the two States in

\footnotetext{
${ }^{64}$ Indonesia was, in the words of former Indonesian Foreign Minister Mochtar, "taken to the cleaners" by Australia when these agreements were negotiated (quoted in Kaye, 2001, at p. 54).

${ }^{65}$ Treaty between Australia and the Republic of Indonesia on the Zone of Cooperation in an Area between the Indonesian Province of East Timor and Northern Australia, 11 December 1989. For treaty text, see <www.un.org/Depts/los/legislationandtreaties.htm>. See also, Charney and Alexander, International Maritime Boundaries 1993, at pp. 1245-1328.

${ }^{66}$ Indeed, the Timor Gap Treaty, which together with its annexed model production sharing agreement and Petroleum Mining Code runs to in excess of 100 pages.

${ }^{67}$ Treaty between the Kingdom of Thailand and Malaysia Relating to the Delimitation of the Territorial Seas of the Two Countries, 24 October 1979 (entered into force 15 July 1982). Treaty text available at $<$ www.un.org/Depts/los/LEGISLATIONANDTREATIES/PDFFILES/TREATIES/THAMYS1979TS.PDF>. See also, Charney and Alexander, International Maritime Boundaries 1993, at pp. 1091-1098.

${ }^{68}$ Memorandum of Understanding between the Kingdom of Thailand and Malaysia on Delimitation of the Continental Shelf Boundary between the Two Countries in the Gulf of Thailand, 24 October 1979 (entered into force 15 July 1982). Treaty text available at $<$ www.un.org/Depts/los/LEGISLATIONANDTREATIES/PDFFILES/TREATIES/THA-

MYS1979CS.PDF>. See also Charney and Alexander, International Maritime Boundaries 1993, at pp. 1099-1123.
} 
February 1979 that established broad principles for the joint development of "non-living-resources, in particular petroleum," in a joint development area (JDA) whose dimensions reflect the area of overlapping claims. ${ }^{69}$ In addition to specifying the geographical scope of the JDA and the overall purpose of the arrangement, the MoU established the principle of the equitable sharing of costs and proceeds from joint activities and provided for the peaceful resolution of any disputes arising. The duration of the agreement was set at 50 years, to be extended if no boundary agreement is reached within that period.

A further agreement was required in order to deal with complex issues such as the detailed regulations to govern activities in the JDA and on the establishment of a Joint Authority. This agreement dealing with the practicalities of turning the MoU into practice was not signed until May 1990, over eleven years after the first $\mathrm{MoU}$ was signed. ${ }^{70}$ The long pause between the conclusion of the MoU and the agreement on implementing its terms has been ascribed to a number of factors. Salient among these are the fact that changes in the governments of both countries undermined the political will for joint development. Additionally, disputes arose, notably in relation to fishing, which complicated the bilateral political relationship, difficulties emerged in relation to reconciling the parties' differing approaches to managing offshore rights and commercial disputes arose, particularly in respect of previously-granted Thai concessions. ${ }^{71}$ Ultimately these difficulties were overcome and commercially viable oil and gas fields have been discovered within the JDA. ${ }^{72}$

It should be noted that an overlap exists between Vietnam's claims and the most seaward part of the Thai-Malaysian JDA mentioned above. However, in the Thai-Vietnamese maritime boundary treaty of 7 August 1997 there exists a specific indication that the parties, together with Malaysia, "shall enter into negotiations...in order to settle the tripartite overlapping continental shelf claim

${ }^{69}$ Memorandum of Understanding between the Kingdom of Thailand and Malaysia on the Establishment of a Joint Authority for the Exploitation of the Resources of the Sea-Bed in a Defined Area of the Continental Shelf of the Two Countries in the Gulf of Thailand, done on 21 February 1979. Treaty text available at http://www.un.org/Depts/los/LEGISLATIONANDTREATIES/PDFFILES/TREATIES/THAMYS1979CS.PDF>. See also, Charney and Alexander, International Maritime Boundaries 1993, at pp. 1107-1123.

70 Agreement between the Government of Malaysia and the Government of the Kingdom of Thailand on the Constitution and Other Matters Relating to the Establishment of the MalaysiaThailand Joint Authority. See Charney and Alexander, International Maritime Boundaries 1993, at pp. 1111-1123.

${ }^{71}$ See Schofield, C.H., "Unlocking the Seabed Resources of the Gulf of Thailand," Contemporary Southeast Asia 29, no. 2 (August 2007) 286-308, at pp. 292-293.

${ }^{72}$ See also, Schofield and Tan-Mullins "Claims, Conflicts and Cooperation," 75-116, at pp.108111. 
area." ${ }^{, 73}$ At the time of writing a tripartite agreement arising from these negotiations had yet to emerge. ${ }^{74}$

\section{Malaysia-Vietnam}

The agreement concluded by Malaysia and Vietnam in 1992 establishes a long, narrow "Defined Area" in the southeastern part of the Gulf of Thailand for the exploration for and exploitation of seabed petroleum deposits. ${ }^{75}$ The Defined Area corresponds to the two States' overlapping claims to continental shelf and was prompted by oil discoveries made by Malaysian contractors within the disputed zone. ${ }^{76}$ The joint arrangement is set to last for 40 years, subject to reviews and extensions. The agreement offers a framework under which nominees of the two governments can enter into agreements for exploring and exploiting petroleum reserves once the area has been delimited. Costs and revenues are to be shared equally. The joint mechanism is therefore a relatively straightforward commercial arrangement whereby each country's rights are managed by their respective national oil companies (Petronas of Malaysia and PetroVietnam of Vietnam). ${ }^{77}$ As oil and gas discoveries have subsequently been made within the Defined Area the project may be deemed a success. $^{78}$

\footnotetext{
${ }^{73}$ Agreement between the Government of the Kingdom of Thailand and the Government of the Socialist Republic of Vietnam on the Delimitation of the Maritime Boundaries between the Two Countries in the Gulf of Thailand, 9 August 1997 (entered into force 28 February 1998), Article 2. Treaty text available at

$<$ http://www.un.org/Depts/los/LEGISLATIONANDTREATIES/PDFFILES/TREATIES/THAVNM1997MB.PDF>. See also, Charney and Smith, International Maritime Boundaries 2002, at pp. 2,692-2,694.

${ }^{74}$ Schofield, "Unlocking the Seabed Resources of the Gulf of Thailand," 300 and Schofield and Tan-Mullins, "Claims, Conflicts and Cooperation," 112-113.

${ }^{75}$ Memorandum of Understanding between Malaysia and the Socialist Republic of Vietnam for the Exploration and Exploitation of Petroleum in a Defined Area of the Continental Shelf Involving the Two Countries was signed on 5 June 1992 and entered into force on 4 June 1993. See Charney and Alexander, International Maritime Boundaries 1998, at pp. 2335-2344.

${ }^{76}$ See Schofield, "Unlocking the Seabed Resources of the Gulf of Thailand," 297.

77 The two governments do, however, retain a right of veto with regard to any agreements their national oil companies might reach. In practical terms, as Petronas had already issued productionsharing contracts for the overlapping area, PetroVietnam agreed to a commercial arrangement whereby these existing contracts would remain valid and petroleum operations would be directly managed by Petronas.

${ }^{78}$ See, Schofield and Tan-Mullins, "Claims, Conflicts and Cooperation," 111-112.
} 


\section{Colombia-Jamaica}

The 1993 Maritime Delimitation Treaty between Colombia and Jamaica ${ }^{79}$ established a "Joint Regime Area" (JRA) to the west of an agreed maritime boundary. The JRA was defined as being a "zone of joint management, control, exploration and exploitation of the living and non-living resources...pending the determination of the jurisdictional limits of each Party." Within this area, however, two 12-nm-radius areas around the Columbian Seranilla Bank and Bajo Nuevo Cays were excluded. The total area of the JRA is approximately $4,500 \mathrm{~nm}^{2}{ }^{80}$ Within the JRA the parties agrred that they could explore for and exploit the natural resources therein, whether living or non-living, establish and use artificial islands, installations and structures, conduct marine scientific research, and take action to protect and preserve the marine environment and conserve living resources. ${ }^{81}$ With regard to activities relating to the exploration and exploitation of non-living resources, as well as those in respect of marine scientific research and on the protection and preservation of the marine environment, however, the parties are to carry out activities "on a joint basis" reached through agreement between them. ${ }^{82}$ Colombia and Jamaica furthermore agreed that within the JRA each State would have jurisdiction over its own nationals and vessels flying its own flag and they agreed to adopt measures to ensure that the national and vessels of third States would comply with any regulations and measures the parties were to adopt. ${ }^{83}$ The parties also agreed to establish a Joint Commission to "elaborate the modalities for the implementation and carrying out of" activities within the JRA. ${ }^{84}$

\section{Argentina-United Kingdom}

Despite the long-standing sovereignty dispute between Argentina and the United Kingdom (UK) over the Falkland Islands (Islas Malvinas to Argentina), South Georgia and the South Sandwich Islands, the parties have, following their 1982 conflict, sought to improve bilateral relations and this has yielded some maritime cooperative initiatives in the South Atlantic. On 2 November 1990 the two

\footnotetext{
${ }^{79}$ The treaty was signed on 12 November 1993 (entered into force 14 March 1994). Treaty text available at $<$ www.un.org/Depts/los/LEGISLATIONANDTREATIES/PDFFILES/TREATIES/JAMCOL1993MD.PDF>. See also Charney and Alexander, International Maritime Boundaries 1998, at pp. $2179-2204$.

${ }^{80}$ Charney and Alexander, International Maritime Boundaries 1998, at p. 2181.

${ }^{81}$ Colombia-Jamaica Treaty, Article 3(2).

${ }^{82}$ Ibid. Article 3(3).

${ }^{83}$ Ibid. Article 3(5 and 6).

${ }^{84}$ Ibid. Article 4.
} 
countries issued a Joint Statement on the Conservation of Fisheries, ${ }^{85}$ established a South Atlantic Fisheries Commission, and announced the cooperation of the two governments over the conservation of fish stocks between $45^{\circ}$ and $60^{\circ}$ south. Additionally, on 27 September 1995 Argentina and the UK issued a Joint Declaration on Cooperation over Offshore Activities in the South West Atlantic. ${ }^{86}$ The Joint Declaration "coordinated activities" in relation to a "sedimentary structure" in an area defined to the southwest of the disputed islands within which the two governments would cooperate to encourage the exploration and production of hydrocarbons. The area in question has an area of approximately $20,000 \mathrm{~km}^{2}$ (around $5,831 \mathrm{~nm}^{2}$ ). Arguably, these two agreements demonstrate that territorial disputes do not necessarily preclude the possibility of effective utilisation and management of resources, as long as the cooperation is clearly without prejudice to claims to sovereignty. However, this may overstate the case somewhat because the bilateral relationship has deteriorated since the conclusion of these joint arrangements; and, while they still exist in principle, little active cooperation appears to be taking place.

\section{Nigeria-São Tomé and Príncipe}

Nigeria and Sao Tomé and Príncipe concluded a treaty in 2001 establishing a joint zone between them. ${ }^{87}$ The joint zone is the largest such arrangement established to date with an area of $34,540 \mathrm{~km}^{2}$ (around $10,070 \mathrm{~nm}^{2}$ ). The objective of the joint arrangement is to exploit and share the natural resources of the joint zone, especially seabed hydrocarbons. Revenues to be derived from the exploitation of the resources within the joint zone are to be shared on the basis of 60 per cent to Nigeria and 40 per cent to Sao Tomé and Príncipe. ${ }^{88}$ One of the innovative aspects of the joint agreement is that it specifically addresses maritime security issues. The agreement establishes a Joint Ministerial Council and a Joint Authority (since renamed the Joint Development Authority or JDA). In addition

\footnotetext{
${ }^{85}$ See, Churchill, R.R., "Falkland Islands - Maritime Jurisdiction and Cooperative Arrangements with Argentina," Current Legal Developments, International and Comparative Law Quarterly, 46 (1997) 463-477, at pp. 463-467.

${ }^{86}$ Ibid. 468-471.

${ }^{87}$ Treaty between the Federal Republic of Nigeria and the Democratic Republic of Sao Tomé and Principe on the Joint Development of Petroleum and other Resources, in Respect of Areas of the Exclusive Economic Zone of the Two States, 21 February 2001 (entered into force 16 January 2003), Article 4. For treaty text see: <www.un.org/Depts/los/legislationandtreaties.htm>. See also, Colson and Smith, International Maritime Boundaries, at pp. 3638-3682.

${ }^{88}$ Nigeria-Sao Tomé and Príncipe Treaty, Articles 3 and 18 and Colson and Smith, International Maritime Boundaries 3638. See also, Groves, H., "Offshore Oil and Gas Resources: Economics, Politics and the Rule of Law in the Nigeria-Sao Tomé e Príncipe Joint Development Zone," Journal of International Affairs 59, 1 (Fall/Winter 2005) at pp. 81-96.
} 
to its primary function of managing activities in relation to the exploration for and exploitation of the natural resources within the joint zone, the JDA is tasked with "controlling the movements into, within and out of the Zone of vessels, aircraft, structures, equipment and people," the establishment of safety zones and restricted zones within the joint zone, regulating marine scientific research and preserving the marine environment within the joint zone. ${ }^{89}$ The Joint Authority is also to request action from the relevant authorities of the parties in relation to search and rescue operations in the joint zone, the prevention and remedying of pollution and the "deterrence and suppression of terrorist or other threats to vessels and structures engaged in development activities in the Zone." 90 The Nigeria and Sao Tomé and Príncipe agreement also includes specific provisions relating to security and policing in the joint zone, according to which the parties are to "jointly conduct defence or police activities throughout the joint zone.""

\section{Australia-Timor Leste (East Timor) in the Timor Sea}

Prior to achieving independence, the East Timorese government in waiting, together with the United Nations Transitional Authority for East Timor (UNTAET) had made it clear that East Timor would not be bound by any of the agreements related to East Timor's territory entered into by Jakarta - including the Timor Gap joint development zone mentioned above. In order to safeguard ongoing seabed resource developments in the Timor Sea, a new agreement, Timor Sea Treaty (TST) was signed between Australia and East Timor on the day that East Timor became independent. ${ }^{92}$ The TST established a Joint Petroleum Development Area (JPDA), which coincides with the central part of the old Australia-Indonesia joint zone (Zone A). Whereas in the past revenues from Zone A had been shared between Australia and Indonesia on an equal basis, under the TST revenues from seabed resources exploited within the JPDA are split 90:10 in East Timor's favour.

\footnotetext{
${ }^{89}$ Ibid. Article 9.

${ }^{90}$ Ibid. Article 9.

${ }^{91}$ Ibid. Article 43. The parties are able to conduct such activities independently but are also to consult with one another. See also Schofield, C.H., "Cooperative Mechanisms and Maritime Security in Areas of Overlapping Claims to Maritime Jurisdiction,” pp. 99-115 in Cozens, P. and Mossop, J., eds., Capacity Building for Maritime Security Cooperation in the Asia-Pacific (Centre for Strategic Studies: New Zealand 2005).

92 Timor Sea Treaty (Dili, 20 May 2002, entry into force 2 April 2003). For treaty text, see $<$ www.un.org/Depts/los/LEGISLATIONANDTREATIES/PDFFILES/TREATIES/AUSTLS2002TST.PDF>.
} 
Complications then arose, especially in relation to the Greater Sunrise complex of fields. ${ }^{93}$ Unitization agreements between Australia and East Timor were signed, but East Timor opted to delay ratification. ${ }^{94}$ It became clear that according to the unitization agreements 20.1 percent of Greater Sunrise lies within the JPDA with the remaining 79.9 per cent falling on what Australia regards as its side of the line. Consequently, East Timor was set to benefit from only 18.1 percent of the proceeds from Greater Sunrise (90 percent share of the 20.1 percent of the field falling within the JPDA). East Timor subsequently argued that it was not bound by the dimensions of the "Timor Gap" defined by previous AustraliaIndonesia boundary agreements and claimed areas adjacent to the JPDA. The delimitation negotiations that ensued proved complex and contentious.

Ultimately, however, Australia and East Timor were able to overcome the barriers to agreement and the Treaty on Certain Maritime Arrangements in the Timor Sea (CMATS) was signed in 2006. ${ }^{95}$ The treaty establishes a further interim resource sharing agreement whose area of application is coincident with the 'Unit Area' defined in the previously negotiated unitization agreement and therefore encompasses the Greater Sunrise complex of fields. The agreement provides for the equal sharing of revenues deriving from the upstream exploitation of petroleum resources within this zone. ${ }^{96}$ The CMATS is without prejudice to either side's claims to maritime delimitation ${ }^{97}$ and includes stringent requirements for a moratorium on claims while the treaty is in force. ${ }^{98}$ The parties

\footnotetext{
${ }^{93}$ C.H. Schofield, "Dividing the Resources of the Timor Sea: A Matter of Life and Death for East Timor," Contemporary Southeast Asia, 27(2) (August 2005), 255-280.

${ }^{94}$ This agreement is often referred to as the Greater Sunrise International Unitisation Agreement, or Sunrise IUA. Memorandum of Understanding between the Government of the Democratic Republic of East Timor and the Government of Australia concerning an International Unitization Agreement for the Greater Sunrise field, Dili, 20 May 2002. Source: United Nations, $<$ www.un.org/Depts/los/LEGISLATIONANDTREATIES/PDFFILES/TREATIES/AUSTLS2002SUN.PDF>, and, Agreement between the Government of Australia and the Government of the Democratic Republic of Timor-Leste relating to the Unitization of the Sunrise and Troubadour fields, Dili, 6 March 2003. Source: United Nations, $<$ www.un.org/Depts/los/LEGISLATIONANDTREATIES/PDFFILES/TREATIES/AUSTLS2003UNI.PDF>.

${ }^{95}$ Transcript of the Prime Minister, the Hon John Howard, MP, Joint Press Conference, Philip Street, Sydney, 12 January $2006<$ www.pm.gov.au/news/interviews/Interview1744.html>. For a copy of the treaty text see: <www.laohamutuk.org/Oil/Boundary/CMATS per cent20text.htm $>$.

${ }^{96}$ Consequently, rather than an 18.1 per cent share in Greater Sunrise as would have been the case under the earlier accords, East Timor stands to gain a full 50 percent share in the revenues deriving from the development of those fields..

${ }^{97}$ CMATS, Article 2.

98 The parties are restricted from the direct or indirect initiation of, or participation in, any proceedings relating to maritime boundary delimitation in the Timor Sea before "any court, tribunal or other dispute resolution mechanism" or even raising such issues in "any international organisation." CMATS, Article 4.
} 
agreed to defer their claims to maritime jurisdiction and boundaries in the Timor Sea for up to 50 years. ${ }^{99}$ The treaty will, however, lapse if either a development plan for Greater Sunrise has not been approved within six years or production has not started within 10 years from the agreement entering into force. ${ }^{100}$ CMATS also provides for East Timorese jurisdiction over the water column above the JPDA $^{101}$ and serves to establish a bilateral joint Maritime Commission to "constitute a focal point for bilateral consultations with regard to maritime matters of interest to the Parties."102

\section{Joint Fishing Zones in East Asia}

Three joint fisheries agreements, which emerged following the ratification of UNCLOS, declaration of EEZs by China, Japan and the Republic of Korea and resulting overlapping maritime claims, may be considered together. The agreements in question are: the China-Japan agreement of 11 November 1997 relating to part of the East China Sea; the Japan-Korea agreement of January 2000 in respect of parts of both the East China Sea and Sea of Japan (East Sea to Korea); and the China-Korea of 30 June 2001 dealing with parts of the Yellow Sea. ${ }^{103}$

These joint agreements are of a provisional nature and are without prejudice to final maritime boundary delimitation. Such joint arrangements have drawbacks, notably that they provide for enforcement on a flag State basis with minimal joint enforcement envisaged, and they include no provisions for enforcement against third parties (such as, for example, Taiwan which is a significant fishing entity in the waters concerned). Furthermore, they encompass only part of the picture and substantial "current fishing patterns" zones persist where fishing is uncoordinated and unregulated. Nonetheless, they represent a positive step towards cooperative, joint solutions to shared problems and a

\footnotetext{
${ }^{99}$ Or, "until the date five years after the exploitation" of the area covered by the treaty ceases, "whichever occurs earlier," CMATS, Article 12.

${ }^{100}$ CMATS, Article 12.

${ }^{101}$ CMATS, Article 8 refers to a line which is defined by means of a list of coordinates of latitude and longitude, referred to World Geodetic System 84 and joined by geodesic lines, contained in a treaty Annex. The line so defined is consistent with the southern boundary of the JPDA with Australia to exercise jurisdiction to the south and East Timor to the north.

${ }^{102}$ CMATS, Article 9. For a more in depth analysis of the CMATS Treaty see, Schofield, C.H., "Minding the Gap: The Australia - East Timor Treaty on Certain Maritime Arrangements in the Timor Sea," International Journal of Marine and Coastal Law, 22, 2 (2007) at pp. 189-234.

${ }^{103}$ The China - Japan agreement was signed on 11 November 1997 and entered into force on 1 June 2000; the South Korea - Japan agreement entered into force in January 1999; and the China South Korea agreement entered into force on 30 June 2001. See S.P. Kim, "The UN Convention on the Law of the Sea and New Fisheries Agreements in North East Asia," Marine Policy, 27 (2003) 97-109.
} 
potentially useful application of maritime joint development concepts to living resources. ${ }^{104}$

\section{Cambodia - Thailand}

On 18 June 2001, Cambodia and Thailand signed a Memorandum of Understanding regarding the Area of their Overlapping Claims to the Continental Shelf in the Gulf of Thailand. ${ }^{105}$ The area covered by the MoU appears to coincide with the parties' large overlapping claims area - an area believed to be highly prospective with respect to seabed hydrocarbon resources. ${ }^{106}$ Cambodia and Thailand have been engaged in negotiations over this area of overlap since the early 1990s without realising an agreement. Indeed, the MoU signed in 2001 has been aptly described as merely "an agreement-to-agree."107 It does, however, mark potentially significant progress as it separates delimitation of a lateral maritime boundary in the vicinity of the terminus of the land boundary on the coast in the north, from joint development of the area of overlapping claims towards the centre of the Gulf, south of the $11^{\circ}$ north parallel of latitude. The negotiations towards delimitation and joint development are to be conducted "simultaneously" and represent "an indivisible package."108 Although the MoU mentioned "accelerated negotiation," 109 no agreement has yet been realized. Nonetheless, the conclusion of the MoU and the ensuing (and ongoing) negotiations must be considered a substantial positive step forward towards resolution of this longstanding maritime dispute.

\section{China-Japan}

It was reported on 16 June 2008 that China and Japan had reached "principled consensus" on cooperation in the East China Sea. ${ }^{110}$ The broad area of overlap between the parties' claim in East China Sea results from their radically different

\footnotetext{
${ }^{104}$ See, Schofield, "Cooperative Mechanisms and Maritime Security."

${ }^{105}$ Colson and Smith, International Maritime Boundaries, at pp. 3743-3744.

${ }^{106}$ It can be inferred that the area of overlap between the parties has been reduced following the resolution of Cambodia and Vietnam's sovereignty dispute over islands. Uncertainty does, however, persist in relation to the southern limit of the area covered by the MoU. See McDorman, T.L., "Maritime Boundary Delimitation in the Gulf of Thailand," Hogaku Shimpo [The Chuo Law Review], CIX, no. 5-6 (March 2003) 253-280, at pp. 278-279. See also Schofield, "Unlocking the Seabed Resources of the Gulf of Thailand," 301-303 and Schofield and Tan-Mullins, "Claims, Conflicts and Cooperation," 113-115.

${ }^{107}$ McDorman, "Maritime Boundary Delimitation," 277.

${ }^{108}$ Cambodia-Thailand MoU, Article 2.

109 Ibid.

110 "China, Japan reach principled consensus on East China Sea issue," Xinhua News Agency, 18 June $2008<$ www.chinadaily.com.cn/china/2008-06/18/content_6774860.htm>.
} 
views on the method of maritime delimitation to be applied - Japan basing its claim on equidistance and China on natural prolongation principles which would set a boundary line coincident with the Okinawa Trough, leaving much of the East China Sea on the Chinese side of the line. As a "first step" towards making the East China Sea a "sea of peace cooperation and friendship," China and Japan agreed to joint development of a specified block of seabed. ${ }^{111}$ This represents a realisation of the pledge first made by Chinese Premier Wen Jiabao and then Japanese Prime Minister Abe in April 2007 and reiterated by Hu Jintao and Abe's successor, Prime Minister Fukuda, in May 2008. ${ }^{112}$ The joint area to be explored "under the principle of mutual benefit," straddles the median line between the parties' coasts and has an area of approximately $2,700 \mathrm{~km}^{2} .113$ The proposed joint zone does not, however, straddle the median line evenly. Instead, the vast majority of the proposed zone is located on the Japanese side of the median line with only the northwestern corner of the joint area on the Chinese side of the line. Additionally, the two countries agreed to allow a Japanese corporation to invest in the Chinese entity already engaged in development activities in relation to the Chunxiao gas field (called the Shirakaba gas field by Japan), located on the Chinese side of but in close proximity to the theoretical median line. The June 2008 agreement makes it clear that cooperation will be entered into "in the transitional period prior to delimitation without prejudicing their respective legal positions."114 Further, potentially challenging negotiations are anticipated regarding conversion of this agreement in principle into a formal treaty and with regard to other disputed gas fields in close proximity to the median line in the East China Sea.

\section{Conclusions}

It is clear from the foregoing review that joint development has proved a popular approach and that numerous examples exist in State practice. Fundamentally, when faced with a deadlock, States have seen the merit in cooperative arrangements that provide an alternative when negotiations become deadlocked, enabling the parties to sidestep seemingly intractable maritime disputes. Maritime

\footnotetext{
${ }^{111}$ Ibid.

${ }^{112}$ See Manicom, J., "Hu-Fukuda Summit: The East China Sea Dispute," China Elections and Governance, <http://en.chinaelections.org/newsinfo.asp?newsid=17841>; and, "Fukuda, Hu Put Focus on Future," Japan Times, 8 May 2008, <http://search.japantimes.co.jp/cgibin/nn20080508a1.html>.

113 "China, Japan reach principled consensus on East China Sea issue," Xinhua News Agency, 18 June 2008. See also "Japan, China Agree on Investment, Joint Gas Project in E. China Sea," Kyodo New Agency, 18 June 2008 $<$ http://home.kyodo.co.jp/modules/fstStory/index.php?storyid=384582>.

${ }^{114}$ Ibid.
} 
joint development thus allows intractable and contentious disputes to be circumvented in such a way that the pragmatic development or management of the resources or environment in the area of overlapping claims can proceed without delay. In this context it has been argued that joint development agreements offer a means to shift the emphasis to "a fair division of the resources at stake, rather than on the determination of an artificial line."

A potentially crucial attraction of the joint development option, either in addition to or instead of a maritime boundary, is that it offers the benefit of removing some of the uncertainty inherent in the delimitation of a final and binding maritime boundary. The possible presence of valuable resources in the area to be delimited may act as an incentive for the parties to claim a particular offshore area, but this factor can also serve to make them cautious about dividing the area of overlapping claims for fear that the resources in question may eventually be discovered on the "wrong" side of the line. This scenario may be especially the case for potential seabed hydrocarbon resources where uncertainty over the precise location of reserves can serve as a major deterrent to the delimitation of a boundary line. Entering into a joint development arrangement helps to defuse this concern as both parties are guaranteed at least a share of any resources found.

Existing State practice can be regarded as diverse, and this underscores flexibility of the joint development option. Joint development has been applied to a variety of jurisdictional zones, to both living and non-living resources, and can also include reference to security issues. The parties to a joint development mechanism may also specify the duration of the arrangement and retain considerable flexibility both regarding the regime that will govern activities within the specified joint zone as well as regarding the precise geographic area that that the joint regime will apply to. Concerning the latter point, however, it has been observed that the uncritical acceptance of competing unilateral maritime claims as the limits of a joint development zone is potentially problematic, as this serves to encourage, reward and to some extent legitimise excessive claims, "without prejudice" clauses notwithstanding. ${ }^{116}$

The cooperative maritime arrangements reviewed above are all consistent with international law, especially UNCLOS Articles 74(3) and 83(3), and include a number of common components. They all feature a formal agreement setting the terms of the arrangement, notably the specific geographical area to which it applies and definition of the resources to which the arrangement applies together with agreement on the laws and jurisdiction governing exploration, operations and revenue sharing. Another common component of maritime joint development

115 E.L. Richardson, "Jan Mayen in Perspective," American Journal of International Law 82 (1988), at pp. 443-458.

${ }^{116}$ See Schofield, "Cooperative Mechanisms and Maritime Security." 
practice includes robust "without prejudice" clauses designed to safeguard existing claims. Such a sovereignty neutral approach allows joint activities to proceed without compromising jurisdictional claims.

In most examples it is also clear that only the parties to the agreement have claims to the area designated as a joint development zone. Where this is not the case, for instance in respect of the joint development zones established between Japan and South Korea, parts of which are also claimed by China, developments in the joint zone may well be compromised. Alternatively, as in the joint development area between Malaysia and Thailand, part of which is also subject to claims on the part of Vietnam, such claims will necessitate further agreements.

A further crucial component for joint development, as for any arrangement reached through negotiations, is political will. In the case of joint development though, such political does needs to be sustained over time. Where seabed resource development is contemplated it is worth considering that oil companies often embark on resource development projects with timelines measured in decades, meaning that any joint development arrangement concluded between interested States is likely to continue, and needs to be sustained, far beyond the lifetime of the governments that enter into it. The difficulties experienced by the Thai and Malaysian governments in converting their agreement in principle on joint development into a fully functioning cooperative mechanism provides a good of example of the problems that can occur. Similarly, the Argentina-UK experience in the South Atlantic, where the underlying sovereignty dispute has not been addressed, resources have not been discovered, and political will has waned over time is an instructive case.

It has therefore been persuasively argued that joint development should not be viewed as some kind of panacea or as a "last gasp" solution applicable simply because a deadlock in maritime delimitation negotiations has been reached, and that " $\mathrm{t}]$ he conclusion of any joint development arrangement, in the absence of the appropriate level of consent between the parties, is merely redrafting the problem and possibly complicating it further." ${ }^{117}$ It is also worth observing that the mere existence of a joint development mechanism does not in itself guarantee cooperation and that, furthermore, it certainly does not guarantee that sought after resources will actually be discovered in the joint zone. Nonetheless, it is abundantly clear that maritime joint development zones represent a valuable and arguably increasingly popular practical means to overcome intractable maritime disputes and to blur the lines of competing

117 Stormont, W.G. and Townsend-Gault, I., "Offshore Petroleum Joint Development Arrangements: Functional Instrument? Compromise? Obligation?" in The Peaceful Management of Transboundary Resources, G.H. Blake, C.L. Sien, C.E.R. Grundy-Warr, M.A. Pratt, and C.H. Schofield, eds. (Graham and Trotman 1995), pp. 51-76. 
maritime claims so that cooperative development and management of ocean resources can proceed. 